\title{
PENGARUH PENAMBAHAN TEPUNG AMPAS KELAPA DENGAN TEPUNG TAPIOKA TERHADAP COOKIES
}

\author{
Sudirman, S.TP(1) dan Retti Ninsix, S.TP., MP ${ }^{(2)}$ \\ ${ }^{(1)}$ Alumni Teknologi Pangan FAPERTA UNISI \\ ${ }^{(2)}$ Dosen Teknologi Pangan FAPERTA UNISI
}

\begin{abstract}
Abstrak
Penelitian dengan judul Pengaruh Penambahan Tepung Ampas Kelapa dengan Tepung Tapioka Terhadap Mutu Cookies bertujuan untuk mengetahui tentang pengaruh penambahan tepung ampas kelapa dengan tepung tapioka terhadap mutu cookies. Penelitian ini dilaksanakan di Laboratorium Teknilogi Pangan Fakultas Pertanian Universitas Islam Indragiri dan analisa di lakukan di Laboratorium Fakultas Teknologi Pertanian Universitas Andalas Padang pada bulan November 2013 sampai Desember 2014.

Rancangan percobaan yang digunakan di dalam penelitian ini adalah Rancangan Acak Lengkap (RAL)yang terdiri dari empat perlakuan yaitu :A = $85 \%$ tepung ampas kelapa $+15 \%$ tepung tapioka, $\mathrm{B}=70 \%$ tepung ampas kelapa + $30 \%$ tepung tapioka, $\mathrm{C}=55 \%$ tepung ampas kelapa $+45 \%$ tepung tapioka, dan $\mathrm{D}=$ $40 \%$ tepung ampas kelapa $+60 \%$ tepung tapioka. Perlakuan ini diulang sebanyak 3 kali sehingga diperoleh pula perlakuan $3 \times 4$ dengan jumlah 12 unit percobaan. Hasil analisa dianalisis secara statistik, j ika $\mathrm{F}$ hitung $>$ dari $\mathrm{F}$ tabel, maka dilakukan uji lanjut BNJ tarafnya 5\%.

Hasil yang terbaik dari penelitian ini adalah perlakuan $\mathrm{Al}(85 \%$ penambahan tepung ampas kelapa $+15 \%$ tepung tapioka ) ) dengan kadar air 4,42 \%, kadar protein 6,67 \%, kadar lemak 13,71\%, serat kasar 8,50 \%, kadar karbohidrat $73,50 \%$ dan dengan uji organoleptik untuk warna 4,55, rasa 4,30, aroma 4,02, dan tekstur 4,40.
\end{abstract}

Kata kunci : Tepung Ampas Kelapa dengan Tepung Tapioka, Cookie.

\section{PENDAHULUAN}

Kue adalah makanan ringan yang bukan makanan utama.Kue berasal dari kata Tionghoa, kemungkinan besar bahasa Hokkien. Secara harafiah kue seringkali diartikan sebagai makanan ringan yang dibuat dari tepung.Baiktepung beras maupun tepung terigu.Kue kering sudah lama kita kenaI dan kue kering sangat enak untuk dihidangkan.Dalam setiap kesempatan kue kering bisa menjadi sungguhan yang menarik, Contoh kue cookies.
Cookies merupakan kue kering yang renyah.tipis.datar (gepeng) dan biasanya berukuran kecil (Smith,1972). Pada satandar industri.cookies adalah makanan ringan yang dibuat dari adonan lunak yang mengandung bahan dasar terigu, pengembang, kadar lemak tinggi, renyah dan apabila dipatahkan penampang teksturrnya kurang padat. Bahan pembuat cookies dibagi menjadi dua menurut fungsinya yaitu bahan pembentuk struktur meliputi tepung susu skim dan putih telur sedangkan bahan 
pendukung kerenyahan meliputi gula, shortening, bahan pengembang, dan kuning telur.

Cookies juga dapat bersifat fungsional bila di dalam proses pembuatannya ditambahkan bahan yang mempunyai aktivitas fisiologi dengan memberikan efek fositif bagi kesehatan tubuh, misalnya cookies yang diperkaya dengan serat, kalsium atau provitamin A (Muchtar dan Wijaya 1996). Cookies terbuat dari bahan dsar tepung terigu yang dicampur dengan bahanbahan lain. Tepung terigu merupakan bubuk halus berasal sari buji gandum. Sampai saat ini, Negara kita masih mengimport bahan baku gandum dari luar negri. Untuk mengurang ketergantungan pada tepung terigu. Salah satu alternatif adalah dengan penggunaan tepung ampas kelapa.

Ampas kelapa merupakan hasil samping atau limbah dari prose $4 \mathrm{~s}$ pembuatan santan maupun pengolahan minyak kelapa.Ampas kelapa merupakan limbah terbuang yang masih belum banyak dimanfaatkan secara maksimal. Menurut Barlina kambuan dan Lay (1997), ampas kelapa mempunyai kandungan gizi yang cukup tinggi, sehingga dapat diolah lebih lanjut menjadi tepung ampas kelapa sebagai salah satu bahan baku produk pangan. Hasil analisa tepung ampas kelapa oleh Berlina et al (1997), diperoleh kadar protein 4,11 \%. Serat kasar 30,58\%, lemak $15,89 \%$, kadar air 4,65\%, kadar abu $0,66 \%$, dan karbohidrat 74,69\%

Kebutuhan serat makanan (Dietary Fiber) untuk kesehatannya dapat diperoleh dalam produk makanan.Produk kue kering pada umumnya berbasis terigu sehingga hampir tidak mengandung serat makanan yang dibutuhkan tubuh. Sehingga perlu dimodifiokasi dengan penambahan bahan serat tinggi.
Keberadaan serat makanan dalam menu sehari-hari terbukti dapat menjaga dan meningkatkan fungsi saluran cerna serta dapat menjaga kesehatan tubuh, terutama dalam upaya mengindari berbagai penyakit degeneratif, seperti obesitas, diabetes melitus, dan penyakit kardiovaskuler (Wildman et al, 2000, Joseph, 2002.

Menurut Marliyati dan Sulaiman (1990) pada penelitiannya tepung ubi kayu ternyata dapat menggantikan tepung terigu $100 \%$ dalam pembuatan cookies.Namun cookies yang benar-benar masih bermutu baik adalah yang terbuat dari campuran $80 \%$ tepung ubi kayu dan $20 \%$ tepung terigu. Daya terima konsumen pada cookies ini cukup baik berkisar antara biasa sampai suka. Menurut Suharno (1990), tepung ubi kayu mengandung pati $83,8 \%$, lemak $0,9 \%$, protein $1 \%$, serat $2,1 \%$, abu $0,7 \%$. Sehingga baik di subtitusi di dalam pembuatan cookies. Oleh karena itu,perlu alternative perbaikan mutu nutrisi dari segi serat kasar kue kering. Salah satu sumber serat yang dapat dimanfaatkan dalam produk makanan adalah tepung ampas kelapa yang dipariasikan dengan tepung tapioka sehingga menghasilkan cookies yang bermutu baik.

Menurut Sarota, Mulyani, dkk, (2012) dari hasil penelitiannya pembuatan cookies dari pemanfaatan tepung ampas mangrove diperoleh hasil terbaik dengan perbandingan tepung terigu $70 \%$ dan tepung ampas mangrove $30 \%$ dan penambahan margarine $\quad 45 \% \quad(\mathrm{v} / \mathrm{b}) \quad$ yang menghasilkan cookies dengan kriteria kadar air $3,9343 \%$, protein $6,2745 \%$, lemak $22,4180 \%$, dan nilai serat kasar $3,4456 \%$.

Berdasarkan penjelasan di atas, maka penulis telah melakukan penelitian 
dengan judul "Pengaruh Penambahan Tepung Ampas Kelapa dengan Tepung Tapioka terhadap Mutu Cookies.

\section{Tujuan Penelitian}

Penelitian ini bertujuan untuk mengetahui tentang pengaruh penambahan tepung ampas kelapa dengan tepung tapioka terhadap mutu cookies.

\section{Manfaat Penelitian}

Manfaat penelitian ini adalah :

1. Untuk meningkatkan pemanfaatkan limbah ampas kelapa menjadi tepung sehingga dapat dimanfaatkan sebagai salah satu bahan baku di dalam pengolahan produk pangan.

2. Sebagai informasi bagi masyarakat di dalam pembuatan cookiesdengan penambahan tepung ampas kelapa dengan tepung tapioka.

\section{METODOLOGI PENELITIAN}

\section{Bahan}

Bahan yang digunakan di dalam pembuatan cookies ini yaitu tepung ampas kelapa, tepung tapioka, tepung terigu, air, garam, telur, soda, gula, mentega sedangkan untuk bahan analisa kimia yaitu selanium mix, $\mathrm{H} 2 \mathrm{~S} 04$, $\mathrm{NaOH}$, asam borat, Hel, alkohol.

\section{Alat}

Alat yang digunakan di dalam penelitian ini yaitu baskom, sendok, pengaduk, oven, kompor.Serta peralatan laboratorium untuk pengujian kimia yaitu cawan alumanium, oven, desikator, timbangan analitik, labu kjeldahl, labu ukur, pipet, alat destilasi, soxhlet, Elenmeyer, kertas saring.

\section{Metode Penelitian}

Rancangan percobaan yang digunakan di dalam penelitian ini adalah Rancangan Acak Lengkap (RAL)yang terdiri dari empat perlakuan yaitu :

$\mathrm{A}=85 \%$ tepung ampas kelapa $+15 \%$ tepung tapioka

$\mathrm{B}=70 \%$ tepung ampas kelapa $+30 \%$ tepung tapioka

$\mathrm{C}=55 \%$ tepung ampas kelapa $+45 \%$ tepung tapioka

$\mathrm{D}=40 \%$ tepung ampas kelapa $+60 \%$ tepung tapioka

Perlakuan ini diulang sebanyak 3 kali sehingga diperoleh pula perlakuan $3 \times 4$ denganjumlah 12 unit percobaan.

\section{HASIL DAN PEMBAHASAN}

\section{Kadar Air}

Kadar air adalah persentase kandungan air suatu bahan, yang dinyatakan berdasarlrnn berat basah (wet basis) atau berdasarkan berat kering (dry basis) (Syarief dan Halid, 1991). Kadar air yang didapat dari analisis pengaruh penambahan tepung ampas kelapa dengan tepung tapioka terhadap mutu cookies berkisar 2,65 \% $4,42 \%$. Kadar air dari cookiesini cukup rendah dan memenuhi standar mutu cookiesberdasarkan SNI ${ }^{\circ} 1-973$ - 1992 yaitu demgan kadar air cookies maksimum $5 \%$.

Hasil analisis sidik ragam terhadap kadar air cookies dapat dilihat bahwa perlakuanpengaruh penambahan tepung ampas kelapa dengan tepung tapioka memberikan pengaruh berbeda nyata terhadap kadar air cookies menurut uji lanjut BNJ pada taraf nyata 5 $\%$. Untuk pengaruh penambahan tepung ampas kelapa dengan tepung tapioka terhadap kadar air cookies dapat dilihat pada Tabel 1 . 
Tabel 1. Pengaruh Penambahan Tepung Ampas Kelapa dengan Tepung Tapioka terhadap Kadar Air Cookies

\begin{tabular}{|c|c|}
\hline \multicolumn{1}{|c|}{ Perlakuan } & \multicolumn{2}{|c|}{ Kadar Air (\%) } \\
\hline B (70\% Tepung Ampas Kelapa + 30\% Tepung Tapioka) & 4,42 a \\
A (85\% Tepung Ampas Kelapa + 15\% Tepung Tapioka) & 4,32 a \\
C (55\% Tepung Ampas Kelapa + 45\% Tepung Tapioka) & 3,08 ab \\
D (40\% Tepung Ampas Kelapa + 60\% Tepung Tapioka) & $2,65 \quad$ b \\
\hline
\end{tabular}

Keterangan : Angka-angka pada jalur atau kolorn yang sarna diikuti oleh huruf yang sarna berbeda nyata rnenurut uji lanjut Tukey pada taraf nyata 5\%

Dari Tabel 1 dapat dilihat bahwa kadar air yang didapat dari analisispengaruh penambahan tepung ampas kelapa dengan tepung tapioka terhadap kadar air cookies ddiperoleh kadar air tertinggi dari perlakuan B (70 \% tepung ampas kelapa $+30 \%$ tepung tapioka) yaitu $4,42 \%$ dan yang terendah pada perlakuan D ( $40 \%$ tepung ampas kelapa $+60 \%$ tepung tapioka ) yaitu 2,65\% Faktor yang mepengaruhi jumlah kadar air cokies pada perlakuan penambahan tepung ampas kelapa dengan tepung tapioka yaitu bahan baku yang digunakan dimana tepung ampas kelapa dengan tepung tapioka mempunyai kadar air yang berbeda, kadar air tepung ampas kelapa 3,37\% (Ninsix, 2011) dan tepung tapioka maksimum 15\% (SNI 01 - 3451 - 1994), perbedaan kadar air dari bahan baku akan menyebabkan kadar air dari cookies akan berbeda. Menurut Winarno (2002), semua bahan makanan mengandung air dalam jumlah yang berbeda beda, baik itu bahan makanan hewani maupun nabati dan kadar air bahan baku akan mempengaruhi kadar air dari produk hasil olahan.

Dari Tabel 1 menunjukan bahwa semakin tinggi persentase penambahan tepung ampas kelapa dan semakin rendah persentase penambahan tepung tapioka maka kadar air pada coolies semakin meningkat. Walaupun pada
Tabel 8 menunjukan bahwahasil analisa dari perlakuan B (70\% tepung ampas kelapa $+30 \%$ tepung tapioka) kadar air $4,42 \%$.lebih tinggi dari perlakuan A (85 \% tepung ampas kelapa $+15 \%$ tepung tapioka) yaitu 4,32 \% namun perlakuan $A$ dengan $B$ menunjukan berbeda tidak nyata menurut uji lanjut BNJ pada taraf nyata $5 \%$.

Hal lain yang menyebabkan tingginya kadar air dengan tingginya persentase tepung ampas kelapa ini di dalam pembuatan cookiesdisebabkan oleh kandungan utama dari tepung ampas kelapa adalah serat kasar dan pati dan serat mempunyai kemampuan mengikat air yang besar dimana persentase serat kasar yang dikandung tepung ampas kelapa yaitu 6,50\% (Ninsix, 2011) sementara tepung tapioka mengandung serat kasar yaitu maksimum 0,60 \% (SNI 01-3451-1994) dan sifat serat di dalam pengolahan mempunyai kemampuan mengikat air yang besar namun sulit untuk dilepaskan kembali walaupun dengan pemanasan. Hal ini didukung oleh Mayer (1980), air yang terikat pada serat dan pati sulit dilepaskan walaupun dengan pemanasan.

\section{Kadar Abu}

Kadar abu merupakan kandungan zat anorganik ataupun unsur-unsur mineral yang didapat dari sisa hasil pembakaran pada suatu bahan makanan (Winamo, 2002). Menurut 
Deman (1997), kandungan abu pada bahan pangan berbeda-beda dan dipengaruhi oleh curah hujan, kondisi tanah, pupuk, dan faktor lainnya. Sampai sekarang telah diketahui ada empat belas unsur mineral yang berbeda jenisnya diperlukan manusia agar memiliki kesehatan dan pertumbuhan yang baik. Yang telah pasti adalah natrium, klor, kalsium, fosfor, magnesium, dan belerang. Unsur ini terdapat dalam tubuh dengan jumlah yang cukup besar yang biasa disebut mineral makro (Winamo, 2002).

Hasil analisis sidik ragam terhadap kadar abu cookies dapat dilihat bahwa perlakuan pengaruh penambahan tepung ampas kelapa dengan tepung tapioka memberikan pengaruh berbeda nyata terhadap kadar abu cookies menurut uji lanjut BNJ pada taraf nyata $5 \%$. Untuk pengaruh penambahan tepung ampas kelapa dengan tepung tapioka terhadap kadar abu cookies dapat dilihat pada Tabel 2.

Tabel 2. Pengaruh Penambaban Tepung Ampas Kelapa dengan Tepung Tapioka terhadap Kadar Abu Cookies

\begin{tabular}{|c|cc|}
\hline \multicolumn{1}{|c|}{ Perlakuan } & \multicolumn{2}{|c|}{ Kadar Abu (\%) } \\
\hline A (85\% Tepung Ampas Kelapa + 15\% Tepung Tapioka) & $1,46 \quad$ a \\
B (70\% Tepung Ampas Kelapa + 30\% Tepung Tapioka) & $1,41 \quad$ ab \\
C (55\% Tepung Ampas Kelapa + 45\% Tepung Tapioka) & $1,38 \quad$ b \\
D (40\% Tepung Ampas Kelapa + 60\% Tepung Tapioka) & $1,29 \quad$ c \\
\hline
\end{tabular}

Keterangan : Angka-angka pada jalur atau kolorn yang sarna diikuti oleh huruf yang sarna berbeda nyata rnenurut uji lanjut Tukey pada taraf nyata 5\%

Dari Tabel 2 dapat dilihat bahwa kadar abu yang didapat dari analisispengaruh penambahan tepung ampas kelapa dengan tepung tapioka terhadap kadar abucookies ddiperoleh kadar abu tertinggi dari perlakuan A (85 $\%$ tepung ampas kelapa $+15 \%$ tepung tapioka) yaitu 1,46\% dan yang terendah pada perlakuan D (40\% tepung ampas kelapa $+60 \%$ tepung teregu ) yaitu 1,29 $\%$. Kadar abu dari perlakuan ini cukup rendah dan $\mathrm{t}$ sesuai dengan standar untuk cookies menurut SNI 01 - 2973 1992 yaitu maksimum 1,5\%.

Dari Tabel 2 dapat dilihat bahwa kadar abusemakin meningkat dengan meningkatnya penambahan tepung ampas kelapa dan semakin menurunnya penambahan tepung tapioka. Tingginya kadar abu dari perlakuan A ( $85 \%$ tepung ampas kelapa $+15 \%$ tepung tapioka) yaitu 1,46\% disebabkan kadar abu dari tepung ampas kelapa 1,25\% (Ninsix, 20011 ) lebih tinggi dari kadar abu tepung tapioka $0,80 \%$ (SNI - 01 3451-1994) sehingga ini akan menyebabkan semakin tinggi penambahan tepung ampas kelapa maka semakin tinggi kadar abu dari cookis dan semakin rendah tepung ampas kelapa yang ditambahkan di dalam pembuatan cookies maka semakin rendah kadar abu dari cookies. Hal ini disebabkan peroses pengolahan tepung ampas kelapa melalui proses pengeringan dengan peroses pemanasan dengan suhu tinggi akan menyebabkan penurunan kadar air dan akan meningkatkan kadar abu dan ini menyebabkan kadar abu tepung ampas kelapa lebih tinggi yaitu 1,25\% .dibandingkan tepung tapioka yaitu 0,80 sehingga ini akan mempengaruhi kadar abu cookis. 
Abu merupakan mineralmineral yang masih terdapat didalam ampas kelapa yang merupakan sisa pembakaran bahan organik. Menurut Barlina (1997), formula yang diolah dengan suhu tingi telah menurunkan kadar air produk, sehinggan kandungan bahan padatan seperti abu dan mineral meningkat. Menurut Sudarmadji et al, (1997), abu adalah zat anorganik sisa hasil pembakaran yang ada pada bahan pangan.

\section{Kadar Protein}

Protein merupakan suatu zat makanan yang sangat penting bagi tubuh, karena zat ini disamping berfungsi sebagai bahan bakar dalam tubuh juga berfungsi sebagai zat pembangun dan pengatur. Protein adalah sumber asam-asam amino yang mengandung unsur-unsur $\mathrm{C}, \mathrm{H}, 0$, dan $\mathrm{N}$ yang tidak dimiliki oleh lemak atau karbohidrat. Molekul protein mengandung pula fosfor, belerang, dan ada jenis protein yang mengandung unsur logam seperti besi dan tembaga (Winamo, 2002).

Hasil analisis sidik ragam terhadap kadar protein cookies dapat dilihat bahwa perlakuan pengaruh penambahan tepung ampas kelapa dengan tepung tapioka memberikan pengaruh tidak berbeda nyata terhadap kadar protein cookies menurut uji lanjut BNJ pada taraf nyata $5 \%$. Untuk pengaruh penambahan tepung ampas kelapa dengan tepung tapioka terhadap kadar protein cookies dapat dilihat pada Tabel 3.

Tabel 3. Pengaruh Penambaban Tepung Ampas Kelapa dengan Tepung Tapioka terhadap Kadar Protein Cookies

\begin{tabular}{|c|l|}
\hline \multicolumn{1}{|c|}{ Perlakuan } & Kadar Protein $(\%)$ \\
\hline D (40\% Tepung Ampas Kelapa + 60\% Tepung Tapioka) & 8,26 \\
C (55\% Tepung Ampas Kelapa + 45\% Tepung Tapioka) & 7,90 \\
B (70\% Tepung Ampas Kelapa + 30\% Tepung Tapioka) & 6,99 \\
A (85\% Tepung Ampas Kelapa + 15\% Tepung Tapioka) & 6,67 \\
\hline
\end{tabular}

Dari Tabel 3 dapat dilihat bahwa kadar protein yang didapat dari analisis pengaruh penambahan tepung ampas kelapa dengan tepung tapioca terhadap kadar proteincookies tidak berbeda nyata menurut uji lanjut BNJ pada taraf nyata $5 \%$ namun dari Tabel 3 dapat dilihat bahwa nilai tertinggi diperoleh kadar perlakuan $\mathrm{D}$ (40 \% tepung ampas kelapa $+60 \%$ tepung tapioka) yaitu 8,26\% dan yang terendah pada perlakuan A (85\% tepung ampas kelapa $+15 \%$ tepung teregu) yaitu 6,67 \%, namun dari semua perlakuan tidak memberikan pengaruh berbeda nyata menurut uji lanjut BNJ pada taraf nyata $5 \%$.

\section{Dari Tabel 3 menunjukan} bahwa semakin tinggi penambahan tepung ampas kelapa dan semakin rendah penambbahan tepung tapioka di dalam pembuatan cookies akan menyebabkan kadar protein cookies akan menurun. Faktor yang mepengaruhi jumlah kadar protein cokies pada perlakuan penambahan tepung ampas kelapa dengan tepung tapioka yaitu bahan baku yang digunakan dimana tepung ampas kelapa dengan tepung tapioka mempunyai kadar protein yang berbeda, kadar protein tepung ampas kelapa 1,15 \% ( Ninsix, 2011 ) dan tepung tapioka $2 \%$ (Suharno, 1990), 
perbedaan kadar protein dari bahan baku akan menyebabkan kadar protein dari cookies akan berbeda. Kadar protein untuk cookies dari semua perlakuan tidak memenuhi standar cookies menurut SNI 01 2973 - 1992 yaitu minimum $9 \%$. Hal ini disebabkan cookies biasanya dibuat dari bahan baku tepung teregu yang mempunyai kadar protein tinggi yaitu minimal 7 \% (SNI, 2009) sementara pada penelitian ini menggunakan tepung ampas kelapa yang mempunyai kadar protein rendah yaitu untuk tepung ampas kelapa 1, $15 \%$ dan tepung tapioka $2 \%$ dan untuk penggunaan tepung teregu sarna untuk semua perlakuan yaitu $20 \%$ bib.

Dari tabel dapat dilihat bahwa antara semua perlakuan untuk kadar protein tidak berbeda nyata menurut uji lanjut BNJ pada taraf nyata 5 $\%$. Hal ini disebabkan karena adanya pengaruh dari suhu yang digunakan selama pengolahan yang dapat menyebabkan denaturasi protein. Menurut Matias ( 2011 ), Protein pangan terdenaturasi jika dipanaskan pada suhu moderat $80{ }^{\circ} \mathrm{C}-90{ }^{\circ} \mathrm{C}$ selama 1 jam atau lebih. Denaturasi adalah perubahan struktur protein dimana pada keadaan terdenaturasi penuh hanya struktur primer aja yang tersisa. Protein tidak lagi memiliki struktur sekunder, tersier dan kuartener.

\section{Kadar Lemak}

Lemak dan minyak merupakan zat makanan yang penting untuk menjaga kesehatan tubuh man usia. Selain itu lemak juga merupakan sumber energi yang lebih efektif dibanding dengan karbohidrat dan protein. Lemak dan minyak terdapat pada hampir semua bahan pang an dengan kandungan yang berbeda-beda ( Winamo, 2002 ).

Hasil analisis sidik ragam terhadap kadar lemak cookies memperlihatkan bahwa perlakuan pengaruh penambahan tepung ampas kelapa dengan tepung tapioka memberikan pengaruh berbeda nyata terhadap kadar lemakcookies menurut uji lanjut BNJ pada taraf nyata $5 \%$. Untuk pengaruh penambahan tepung ampas kelapa dengan tepung tapioka terhadap kadar lemak cookies dapat dilihat pada Tabel 4 .

Tabel 4. Pengaruh Penambaban Tepung Ampas Kelapa dengan Tepung Tapioka terhadap Kadar Lemak Cookies

\begin{tabular}{|c|c|}
\hline Perlakuan & \multicolumn{2}{|c|}{ Kadar Lemak (\%) } \\
\hline A (85\% Tepung Ampas Kelapa + 15\% Tepung Tapioka) & 12,71 a \\
B (70\% Tepung Ampas Kelapa + 30\% Tepung Tapioka) & $12,20 \quad$ b \\
C (55\% Tepung Ampas Kelapa + 45\% Tepung Tapioka) & $11,65 \quad$ bc \\
D (40\% Tepung Ampas Kelapa + 60\% Tepung Tapioka) & $10,78 \quad$ c \\
\hline
\end{tabular}

Keterangan : Angka-angka pada jalur atau kolorn yang sarna diikuti oleh huruf yang sarna berbeda nyata rnenurut uji lanjut Tukey pada taraf nyata 5\%

Dari Tabel 4 dapat dilihat bahwa kadar lemak yang didapat dari analisis pengaruh penambahan tepung ampas kelapa dengan tepung tapioka terhadap kadar lemak cookies diperoleh kadar lemak tertinggi dari perlakuan A $(85 \%$ \% tepung ampas kelapa $+15 \%$ tepung tapioka) yaitu 
$12,71 \%$ dan yang terendah pada perlakuan D (40\% tepung ampas kelapa $+60 \%$ tepung terigu) yaitu $10,78 \%$. Kadar lemaka dari hasil analisis cookies dari pengaruh penambahan tepung ampas kelapa dengan tepung tapioka ini memenuhi standar cookies menurut standar SNI 01 -2973 - 1992 yaitu minimal 9,5\%.

Dari Tabel 4 dapat dilihat bahwa dengan meningkatnya penambahan tepung ampas kelapa dan menurunnya penambahan tepung tapioka di dalam pembuatan cookies maka kadar lemak semakin meningkat. Hal ini disebabkan kadar lemak dari tepung ampas kelapa yaitu $8,13 \%$ sedangkan pada tepung tapioka yaitu 1,9. Sehingga dengan meningkatnya penambahan tepung ampas kelapa di dalam pembuatan cookies akan menyebabkan kadar lemak dari cookies akan meningkat.

Kandungan lemak pada cookies juga sangat dipengaruhi oleh penambahan margarin atau shortening pada pembuatan cookies. Hal ini disebabkan karena margarine mengandung lemak yang tinggi. Menurut Hui (1996), margarine teriri dari 80 - $81 \%$ totallemak. Hal ini didukung juga oleh De Man (1971), margarine mengandungsejumlah besar lipid dan sebagian dari lipid itu terdapat dalam bentuk terikat sebagai lipoprotein. Margarine bila ditambahkan pada adonan, maka adonan tersebut akan mempunyai kandungan kadar lemak yang tinggi (Matz, 1987). Sebagai penambahan tepung ampas kelapa dan tepung tapioka hanya sedikit mempengaruhi kandungan lemak produk cookies tersebut, dikarenakan kandungan lemak tepung ampas ampas kelapa hanya sekitar 8,13 \% (Ninsix, 2011) sedangkan pada tepung tapioka sekitar 0,9 \% (Suhamo, 1990).

\section{Kadar Karbohidrat}

Karbohidrat

mempunyai peranan penting dalam menentukan karakteristik bahan makanan, misalnya rasa, wama, tekstur, dan lain-lain. Sedangkan dalam tubuh, karbohidrat berguna untuk mencegah timbulnya ketosis, pemecahan protein tubuh yang berlebihan, kehilangan mineral, dan berguna untuk membantu metabolisme lemak dan protein. Selain itu beberapa golongan karbohidrat menghasilkan serat-serat (dietaryfiber) yang berguna bagi pencemaan (Winarno, 2002).

Hasil analisis sidik ragam terhadap kadar karbohidrat cookies memperlihatkan bahwa perlakuan pengaruh penambahan tepung ampas kelapa dengan tepung tapioka memberikan pengaruh tidak berbeda nyata terhadap kadar karbohidrat cookies menurut uji lanjut BNJ pada taraf nyata $5 \%$. Untuk pengaruh penambahan tepung ampas kelapa dengan tepung tapioka terhadap kadar karbohidrat cookies dapat dilihat pada Tabel 5.

Tabel 5. Pengaruh Penambahan Tepung Ampas Kelapa dengan Tepung Tapioka terhadap Kadar Karbohidrat Cookies

\begin{tabular}{|c|c|}
\hline Perlakuan & Kadar Lemak (\%) \\
\hline D (40\% Tepung Ampas Kelapa + 60\% Tepung Tapioka) & 78,49 \\
C (55\% Tepung Ampas Kelapa + 45\% Tepung Tapioka) & 75,29 \\
B (70\% Tepung Ampas Kelapa + 30\% Tepung Tapioka) & 74,60 \\
A (85\% Tepung Ampas Kelapa + 15\% Tepung Tapioka) & 73,50 \\
\hline
\end{tabular}


Dari Tabel 5 dapat dilihat bahwa kadar karbohidrat yang didapat dari analisis pengaruh penambahan tepung ampas kelapa dengan tepung tapioca terhadap kadar karbohidrat cookies ddiperoleh kadar karbohidrat tertinggi dari perlakuan D ( $140 \%$ tepung ampas kelapa $+60 \%$ tepung tapioka) yaitu $478,83 \%$ dan yang terendah pada perlakuan A ( $85 \%$ tepung ampas kelapa $+15 \%$ tepung teregu ) yaitu $73,50 \%$. Kadar karbohidrat dari semua perlakuan penambahan tepung ampas kelapa dengan tepung tapioka terhadap mutu cookies memenuhi SNI yaitu untuk kadar karbohidrat minimal $70 \%$.

Kadar karbohidrat sangat dipengaruhi oleh kadar lain dari kandungan lain dari cookies yang dihasilkan.seperti kadar air, kadar abu, kadar lemak, dan kadar protein, semakin tinggi unsur yang dikandung dari unsur lain maka kandungan karbohidrat semakin rendah begitu juga sebaliknya semakin rendah unsur yang dikandung oleh unsur lain maka kandungan karbohidrat semakin tinggi. lni sesuai menurut Winarno (2002) Kadar karbohidrat diference pada bahan sangat ditentukan oleh kandungan lainnya seperti lemak.

\section{Kadar Serat Kasar}

Hasil analisis sidik ragam terhadap kadar serat kasar cookies memperlihatkan bahwa perlakuan pengaruh penambahan tepung ampas kelapa dengan tepung tapioka memberikan pengaruh berbeda nyata terhadap kadar serat kasarcookies menurut uji lanjut BNJ pada taraf nyata $5 \%$. Untuk pengaruh penambahan tepung ampas kelapa dengan tepung tapioka terhadap kadar serat kasar cookies dapat dilihat pada Tabel 6 .

Tabel 6. Pengaruh Penambahan Tepung Ampas Kelapa dengan Tepung Tapioka terhadap Kadar Serat Kasar Cookies

\begin{tabular}{|c|c|}
\hline Perlakuan & \multicolumn{2}{|c|}{ Kadar Lemak (\%) } \\
\hline A (85\% Tepung Ampas Kelapa + 15\% Tepung Tapioka) & 9,50 a \\
B (70\% Tepung Ampas Kelapa + 30\% Tepung Tapioka) & 8,65 a \\
C (55\% Tepung Ampas Kelapa + 45\% Tepung Tapioka) & 8,50 a \\
D (40\% Tepung Ampas Kelapa + 60\% Tepung Tapioka) & $6,54 \quad$ b \\
\hline
\end{tabular}

Keterangan : Angka-angka pada jalur atau kolorn yang sarna diikuti oleh huruf yang sarna berbeda nyata rnenurut uji lanjut Tukey pada taraf nyata 5\%

Dari Tabel 13 dapat dilihat bahwa kadar serat kasar yang didapat dari analisispengaruh penambahan tepung ampas kelapa dengan tepung tapioka terhadap kadar serat kasar cookies ddiperoleh kadar serat kasar tertinggi dari perlakuan A ( $85 \%$ tepung ampas kelapa $+15 \%$ tepung tapioka) yaitu $9,50 \%$ dan yang terendah pada perlakuan D ( $40 \%$ tepung ampas kelapa $+60 \%$ tepung teregu ) yaitu $6,54 \%$.
Hubungan antara perlakuan penambahan tepung ampas kelapa dengan tepung tapioka terhadap kadar serat kasar cookiesbahwa semakin tinggi persentase tepung ampas kelapa yang ditambahkan dan semakin rendah tepung tapioka yang ditambahkan, maka serat kasar dari cookies semakin meningkat. Hal ini disebabkan tepung amapas kelapa mengandung serat kasar 6,50\% (Ninsix, 2011) sedangkan tepung tapioka 
mengandung serat maksimum $60 \%$ (SNI 01-3451-1994) dan ini menyebabkan semakin meningkat jumlah tepung ampas kelapa yang ditambahka di dalam pembuatan cookies akan menyebabkan serat kasar pada cookies akan meningkat. Kadar serat kasar untuk cookies dari perlakuaan penambahan tepung ampas kelapa dengan tepung tapioka dari semua perlakuan tidak memenuhi standar cookiesmenurut SNI 01- 2973-1992 yaitu maksimal 0,5\% .

Tingginya kadar serat kasar cokies pada perlakuan penambahan tepung ampas kelapa dengan tepung tapioka dibandingkan kadar serat kasar menurut SNI 01 - 2973 - 1992 yaitu maksimal 0,5\% disebabkan bahan baku yang digunakan di dalam pembuatan cookies adalah tepung ampas kelapa mempunyai kadar serat kasar yang cukup tinggi yaitu $6,50 \%$ (Ninsix, 2011) dan tepung tapioka $2 \%$ (Suhamo, 1990), perbedaan kadar serat kasar dari bahan baku akan menyebabkan kadar serat kasar dari cookies akan berbeda. SNI 01 - 2973 - 1992 yaitu minimum $9 \%$. Hal ini disebabkan cookies biasanya dibuat dari bahan baku tepung teregu yang mempunyai kadar serat kasar rendah sementara pada penelitian ini menggunakan tepung ampas kelapa yang mempunyai kadar serat kasar tinggi yaitu untuk tepung ampas kelapa 6,50 \% (Ninsix, 2011).

Ini sesuai dengan pendapat Barlina (2007) bahwa keunggulan utama tepung dari ampas kelapa adalah kandungan serat pangannya yangsangat tinggi. Hasil penelitian menunjukkan bahwa kandungan serat pangan total pada tepung kelapa secara signifikan lebih tinggi dibandingkan tepung pisang, kasava, gandum, dan beras. Keunggulan ini dapat dijadikan dasar bagi pemanfaatan tepung kelapa sebagai produk fungsional. Kandungan serat pangan yang sangat tinggi dalam tepung kelapa terbukti berperan penting dalam pencegahan dan pengendalian berbagai penyakit kronis, seperti kanker usus besar, serangan jantung, hipertensi, stroke, dan diabetes mellitus

\section{KESIMPULAN DAN SARAN}

\section{Kesimpulan}

Dari penelitian yang telah dilakukan, yaitu pemanfaatan Tepung Ampas Kelapa dengan Tepung Tapioka terhadap Mutu Cookies, dapat ditarik kesimpulan :

1. Penambahan tepung ampas kelapa dan tepung tapioka memberikan pengaruh berbeda nyata terhadap mutu cookiesyang dihasilkan menurut uji lanjut BNJ pada taraf nyata $5 \%$ terhadap kadar air, kadar abu, kadar lemak., kadar karbohidrat, kadar serat kasar dan uji organoleptik terhadap wama, rasa, aroma, dan tekstur dan tidak memberi pengaruh berbeda nyata terhadap kadar protein.

2. Penambahan tepung ampas kelapa dan tepung tapioka terhadap mutu cookies yang dihasilkan diperoleh hasil analisis berkisar kadar air 2,65 4,42 \%, kadar abu 1,29\% - 1,46, protein 6,67 -8,26 \%, lemak 6,54 $8,50 \%$, dan kada karbohidrat 73,50 $\%-78,49 \%$

3. Hasil yang terbaik dari perlakuan ini yaitu Al (85\% penambahan tepung ampas kelapa $+15 \%$ tepung tapioka) dengan kadar air 4,42 \%, kadar protein $6,67 \%$, kadar lemak 13,71 $\%$, serat kasar 8,50 \%, kadar karbohidrat 73,50\%.

\section{Saran}

Dari hasil penelitian disarankan :

1. Untuk memperoleh cookies yang baik dapat menggunakan 
penambahan $85 \%$ tepung ampas kelapa dan $15 \%$ tepung tapioka.

2. Diharapkan dapat melakukan penelitian lain dari penambahan berbagai jenis tepung lain.

\section{DAFTAR PUSTAKA}

Aswatan, M., 2004.Membuat Mie dan Bihun. Penebar Swadaya, Jakarta. Assosiation Of Official Analitycal Chemist, 2005. Official Method Of Analysis Of The Assosiation Of Official Analitycal Chemist, inc.

Berlina, R, H. Kembuan, dan A. Lay. 1997. Pemanfaatan Ampas Kelapa untuk bahan makanan rendah kalori.Jurnal Penelitian Tanaman Industri. 3 (2) : 56-63.

Belitz, H.D and W. Grosch, 1987., Food Chemistry Tranlation from 2nd Ceremoned by $\mathrm{O}$. Heasdier Verlang Berlin, New York.

(BSN) Badan Standarisasi Nasional. 1992. Pengukuran serat Kasar (SNI 01 2891-1992, Butir 11). BSN, Jakarta.

Damardjati, Djoko S dan Widowati.1993. Prospek Pengembangan Kasava dan Potensi Tepung Kasava dalam Pengembangan Agoindustri di Pedesaan. Dalam pengembangan teknologi pengelolaan Ubi Kayu dalam Munjang Agro-Ekologi di Pedesaan. Balai Penelitian Tanaman Pangan Sukamandi.

Desrosier, N. W., 1988. Teknologi Pengawetan Pangan. Penerjemah UI-Press, Jakarta.

M. Muljohardjo.

Direktorat Gizi. 1996. Daftar Komposisi Makanan. Direktorat Gizi. Departemen Kesehatan RI. Jakarta.
Ginting, Erliana. 2002. Teknologi Penanganan Paskapanen dan Pengolahan Ubi Kayu menjadi Produk antara untuk Mendukung Agroindustri.Buletin Palawijaya No.4:67-83.

Joseph, G.2002. Manfaat Serat Makanan Bagi Kesehatan Kita. Makalah Falsafah Sains, Program Pascasarjana IPB. Bogor, Mei 2002.

Miakiyah, Mulyawati I, dan Haliza W. 2006. Pemanfaatan Ampas Kelapa Limbah Pengolahan Minyak Kelapa Mumi Menjadi Pakan. Prosiding Seminar Nasional Teknologi Petemakan dan Verliner. HIm. 830-834.

Muchtadi D, Wijaya CH. 1996. Pangan Fungsional: Pengenalan dan Perancangan. Makalah pada Seminar Makanan Fungsional dan Keamanan Pangan, 8-9 Juli 1996, Yogyakarta.

Moehyi, S. 1992. Makanan Intitusi dan Jasa Boga. Bhratara, Jakarta.

Purwadaria, HadLK.1989. Teknologi Pasca Panen Ubi Kayu. Institut Pertanian Bogor.

Smith, W. H. 1972. Biscuit, Crakers and Cookies.Applied Science Publisher Ltd, London. VoLI

Suharno.1990. Rancangan Bangun dan Introduksi Model Alat Penepung Ketela Pohon. Laporan Pengabdian Pada Masyarakat. Fakultas Teknologi Pertanian. Universitas Gadjah Mada. Jogyakarta.

Sultan, W. J. 1981.Practical Baking.3 rd Edition.The AVI Publishing Compoany, Inc. Westport Connecticut.

Suismono dan Prihadi Wibowo. 1991. Pengaruh Pengepresan dan Bahan Pengemas Terhadap Mutu dan Rendemen Tepung 
Kasava Selama Penyimpanan.

Media Penelitian Sukamandi

No: 9, Balai Penelitian

Syarief, R. Dan A. Irawati, 1988.

Tanaman Pangan. Sukamandi. Jawa Barat.

Sudarmadji, Slamet, Bambang Haryono dan Suhardi, 1997.

Prosedur Analisa Untuk Bahan

Makanan dan Pertanian. Liberty. Yogyakarta.

Somaatmadja, D., 1985. Pengolahan

Teknolo Pangan. Dapartemen

Perindustrian. BI HP, Bogor.

Soekarto. 1985.Penelitian Organoleptok

untuk Pangan dan Hasil

Pertanian. Bahtara Karya Aksara. Jakarta.

Suryani, A."ddk.2007. Bisnis Kue Kering. Penebar Swadaya, Jakarta.

Pengetahuan Bahan untuk Industri Pertanian. Mediyatama Sarana Perkasa, Jakarta.

Tim Penyusun Jurusan Teknologi Pangan dan Gizi, 1990. Teknologi Pangan dan Agroindustri.Volome 1, Nomor 1-12 Jurusan Jurusan Teknologi Pangan dan Gizi. Fakultas Teknologi Pertanian, Bogor

Wildman,REC, Modeiros, DM. 200. Carbohydrates. Dalam Advanced Human Nutrition. New York: CRC Press. Boca Ratun. P. 6697.

Winarno, F. G. 1997. Kimia Pangan dan gizi. PT.Gamedia Pustaka. Jakarta. 